Research Article/Araştırma Makalesi

\title{
The Effect of Botanical Garden on Socio-Scientific Issues of Students' Perspectives in the Teaching Process: Sustainable Environment
}

\author{
Gülsün KARSLI ${ }^{1}$ (D) , Orhan KARAMUSTAFAOĞLU 2 * (D), Murat KURT ${ }^{3}$ (D) \\ ${ }^{1}$ Amasya University, Education Faculty, Amasya, Turkey, gk0404@hotmail.com \\ 2 Amasya University, Education Faculty, Amasya, Turkey, orhan.karamustafaoglu@amasya.edu.tr \\ ${ }^{3}$ Amasya University, Education Faculty, Amasya, Turkey, murat.kurt@amasya.edu.tr \\ * Corresponding Author: orhan.karamustafaoglu@amasya.edu.tr
}

Article Info

Received: 7 August 2019

Accepted: 17 September 2019

Keywords: Outdoor-school learning, science education, botanical garden

DOI: $10.18009 /$ jcer.603489

Publication Language: Turkish

\begin{abstract}
The aim of research is to design, conduct and implement an exemplary outdoor-school learning environment for Sustainable Environment that can be used in the $5^{\text {th }}$ grade science course and to examine its reflections on students. Case study, one of the qualitative research methods, was used. The research was carried out with 32 students in $5^{\text {th }}$ grade studying in a secondary school in the central district of Ağrı province in the second term of 2018-2019 academic year. In the study, activities were prepared according to the achievements of the $5^{\text {th }}$ grade "Human and Environment" unit in the 2018 Science Education Program. The trip was organized to Ata Botanic Garden, which is one of the extra-school learning environments. The sustainable environmental scale was applied as a pre-test and post-test, and a statistically significant difference were found in favor of the post-test. After the trip, the students stated that they learned a lot from Ata Botanic Garden.
\end{abstract}

To cite this article: Karslı, G., Karamustafaoğlu, O., \& Kurt, M. (2019). Botanik bahçesinin öğretim sürecinde öğrencilerin sosyobilimsel konulara olan bakışlarına etkisi: Sürdürülebilir çevre. Journal of Computer and Education Research, 7 (14), 437-463. DOI: 10.18009/jcer.603489

\section{Botanik Bahçesinin Öğretim Sürecinde Öğrencilerin Sosyobilimsel Konulara Olan Bakışlarına Etkisi: Sürdürülebilir Çevre}

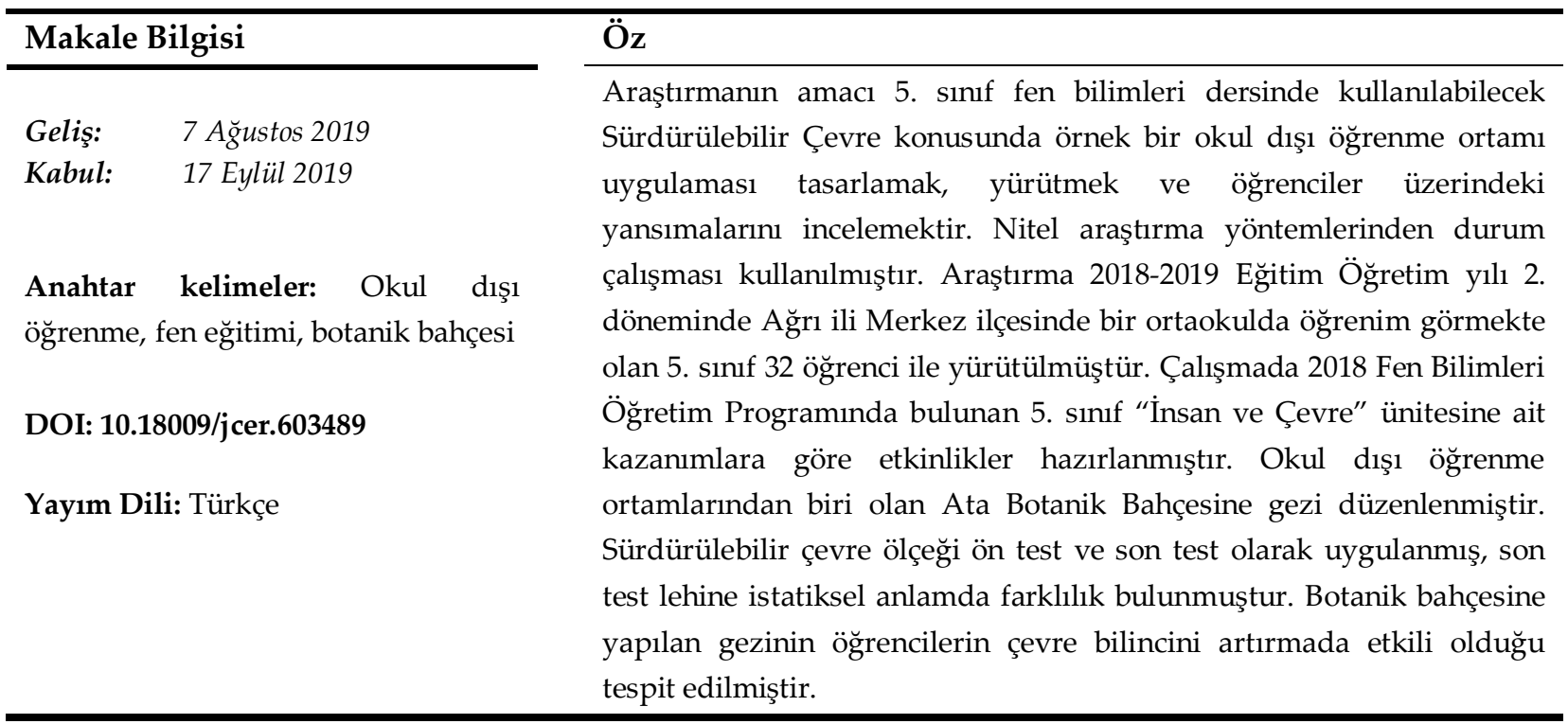




\section{Summary}

\section{The Effect of Botanical Garden on Socio-Scientific Issues of Students' Perspectives in the Teaching Process: Sustainable Environment}

\section{Introduction}

In today's world where everything changes very quickly, various studies are being carried out to ensure the education systems' keeping up with this change. Because the methods and techniques used in education within the scope of that rapid change also change over time. It is diversified and revised according to time, opportunity and student. Given that the right way to meet the necessities of the time is through proper education, it is inevitable to use new methods for quality education. Among the changes in education, learning environments that are limited to school spaces are also changing, especially the framework of the environments is gradually expanding. In this context, the importance of outdoor-school learning environments is increasing day by day. The studies conducted to adapt to the developing and changing conditions have led the educators to different methods and techniques. So, the idea that all areas which can contribute to education as an out-of-school learning environment can be utilized is developed (Laçin-Şimşek, 2011).

By recognizing the opportunities existing his environment, it is aimed for the individual to use these opportunities in the learning process in 2018 Updated Science Curriculum. It is expected to raise science literate individuals who adapt their knowledge and skills to their own lives, use what they have gained from their life experiences to activate their knowledge, are intertwined with human and environment, curious, sensitive to sociological issues. In addition, in 2023 Education Vision, for the purpose of enriching the teaching of schools with out-of-school settings it is aimed to direct the schools to cooperate with the institutions such as museums, science centers and art centers in their regions and to use the extra-school learning environments in parallel with the curricula (MEB, 2018). 
All educational activities carried out outside the classroom or school walls are called "outdoor education". Contrary to popular belief, these planned and programmed activities contribute to classroom learning as a complement to formal education today. Out-of-school learning areas are open to learning by research and investigation involving many living and non-living beings in which many abstract and concrete concepts can be learned in connection with each other such as science, mathematics, art and social sciences (Erten \& Taşçı, 2016) .

Areas such as museums, natural history museums, zoos, planetariums, botanical gardens, universities, research centers, national parks, science centers, industrial establishments, and school gardens are an out-of-school learning environment. Students have the opportunity to experience the science teaching they learn in school in these outdoor-school settings.

Because the facts, concepts and events in the curriculum can be connected with daily life, the out-of-school education environments can be ideal environments in terms of awareness of sociological issues. It is of great importance that individuals who are targeted to be science literate in science teaching have an idea about these issues, put forward their ideas, and discuss about these issues. Therefore, it provides an ideal environment for such discussions to be held in outdoor-school environments.

\section{Method}

The aim of this research is to design and implement an exemplary out-of-school learning environment that can be used in the $5^{\text {th }}$ grade science course and reveal the effect of the trip to the Botanical Garden, an outdoor-school learning environment, to the $5^{\text {th }}$ grade students' perspective on sociological issues.

In this study, case study which is one of the qualitative research methods was used (Kaleli Yılmaz, 2019; Yıldırım \& Şimşek, 2008). In this study, this method was chosen to give information about how to organize a trip to outdoor-school environments and to examine the effects of the trip on the participants. Within this scope, a trip to Ata Botanic Garden was organized and then the data were generated from the answers of the participants to the scale questions. The study was conducted with 32 students in $5^{\text {th }}$ grade. Within the framework of the detailed trip plan, necessary permissions were obtained from parents and institutions. 
As a data collection tool, "Sustainable Environmental Awareness Scale" was used as pre-test and post-test. In addition, 2 promotional brochures and 4 activities were used during the trip.

\section{Results}

According to the results of the analysis, a statistically significant difference was found between the pre-test and post-test scores of the students in favor of the post-test. In the Sustainable Environmental Awareness Scale, the "sufficient" response of the students to each item was $43.8 \%$ and $81.3 \%$; in the last test, it was between $50 \%$ and $87.5 \%$.

After the trip, the students left the trip very happy and satisfied. They expressed their satisfaction in various sentences.

\section{Discussion and Conclusion}

When considering the analysis of the items belonging to Sustainable Environmental Awareness Scale used in the research, in the $5^{\text {th }}$ and $6^{\text {th }}$ items, it was seen that there was no change in the number of respondents who had sufficient answers in the post-test compared to the pre-test. It can be seen an increase in favor of the final test in all other responses. During the visit to the botanical garden, it was concluded that the students whom were affected by the beauty of the environment gained positive awareness of the environment.

It was seen that the students were very excited and happy before the trip. The students who took lots of photos during the trip expressed their happiness from being in the botanical garden in various ways. During the trip, various activities were conducted according to the "human and environment" unit gains. With the activities, human and environment relations were discussed in the botanical garden which is an outdoor-school learning environment and different species were observed together. 


\section{Giriş}

Eğitimde yapılan çeşitli yeniliklerle beraber her geçen gün öğrenme ve öğretme faaliyetleri değişmekte ve gelişmektedir. Eğitim süreçlerinde kullanılan yöntem ve teknikler de değişime uğramakta ve zamana, mekâna, öğrenciye göre çeşitlenip yeniden düzenlenmektedir. Doğru zamanda, doğru yerde, doğru yöntem ve teknikle gerçekleştirilecek olan eğitimde istenilen başarıya ulaşılması kaçınılmazdır. $\mathrm{Bu}$ amaçla eğitim faaliyetleri sadece sınıf ortamları ile sınırlı kalmayıp öğrenme alanlarının çerçevesi giderek genişletilmektedir. Söz konusu çerçevenin genişlemesi kapsamında okul dışı öğrenme ortamları gittikçe önem kazanmaktadır. Özellikle değişen ve gelişen şartlara uyum sağlamak amacı ile eğitim-öğretim alanında yapılan çalışmalar, eğitimcileri alternatif yöntem ve tekniklere yönlendirmektedir. Eğitimde yapılan tüm faaliyetler okul ve sınıf duvarları ile kalmayıp, bu sınırların dışına çıkmaktadır. Eğitime katkısı olabilecek her türlü alandan okul dışı öğrenme ortamı olarak faydalanılabileceği düşüncesi böyle gelişmiştir (Laçin-Şimşek, 2011).

2018 yılında güncellenmiş olan Fen Bilimleri Öğretim Programında yer verilen yetkinliklerden bir tanesi de öğrenmeyi öğrenme yetkinliğidir. Bu yetkinlik çerçevesinde birey öğrenmenin peşine düşer; çevresinde var olan imkânları tanıyarak öğrenme süreçlerinde kullanmasını, yeni bilgi ve becerileri kazanırken bu bilgi ve becerileri işleyip kendine uyarlamasını da öğrenir. Öğrenmeyi öğrenme ile birey edindiği bilgi ve becerilerini her alanda kullanma imkânı bulur ve bu sayede yaşam deneyimlerinden edindikleri bilgileri de harekete geçirmiş olur (Milli Eğitim Bakanlığ1 [MEB], 2018).

Tüm bireylerin fen okuryazarı olarak yetişmesini hedefleyen Fen Bilimleri Öğretim programının özel amaçlarından biri bireylerin insan ve çevre arasındaki ilişkinin anlaması ve bu süreçte bilimsel araştırma yaklaşım ve yöntemleriyle beraber sorunlara çözüm bulmasıdır (MEB, 2018). Bu amaçla insan ve çevre ilişkisinin önemi vurgulanmaktadır. Bireyin yakın çevresinde ve doğada oluşan olayla ilgili ve meraklı olması ve olumlu tutum geliştirmesi amaçlanmıştır. Bir diğer amacı ise bireyin sosyobilimsel konularla ilgilenerek karşılaştırma yeteneği edinip bilimsel düşünme ve doğru karar verebilme becerilerini geliştirmektir (MEB, 2018). Millî Eğitim Bakanlığının 2023 Eğitim Vizyonu'nda Temel Eğitim teması içinde yer alan yenilikçi uygulamalara imkân sağlayan ikinci hedefinin ikinci eyleminde; okulların öğretimini okul dışı ortamlarla zenginleştirmesini amaçlayarak onları bölgelerinde var olan 
müze, bilim merkezi, sanat merkezi gibi kurumlarla iş birliğine yönlendirmektedir. Ortaöğretim temasında yer alan akademik bilginin beceriye dönüşmesini belirten ikinci hedefin Üçüncü eyleminde ise; okul dışı öğrenme ortamlarının öğretim programlarıyla örtük olacak şekilde etkin kullanılması amaçlanmıştır.

Sınıf ya da okul duvarları dışına çıkılarak yapılan tüm eğitimsel faaliyetlere “Sınıf/Okul Dışı Eğitim (outdoor education)” denir. Sanılanın aksine planlı ve programlı yapılan bu faaliyetler günümüzde örgün eğitimin tamamlayıcısı olarak sinıfta gerçekleştirilen öğrenmelere katkı sağlamaktır (Bozdoğan \& Kavcı, 2016). Okul dışı öğrenme alanları fen, matematik, sanat, sosyal bilimler gibi pek çok disiplini birbirine bağlantılı şekilde hem soyut hem somut kavramların öğrenilebileceği, canlı ve canlı olmayan pek çok varlığı içeren araştırma ve inceleme yaparak öğrenmeye açık alanlardır (Erten \& Taşçı, 2016).

Okul dışı öğrenme ortamları, öğrenmenin sadece dört duvar sınıf içinde değil, yaşamla iç içe ve her alanında gerçekleştirilebileceği anlayışına dayanır. Formal öğrenmeye destek olacak şekilde her ortam okul dışı öğrenme ortamı olabilir. Müzeler, doğa tarihi müzeleri, hayvanat bahçeleri, planetaryumlar, botanik bahçeleri, üniversiteler, araştırma merkezleri, sanayi kuruluşları gibi kurum ve kuruluşlar olabileceği gibi sanal ortamlar da olabilir (Eshach, 2007). Saraç, (2017) okul dışı öğrenme ortamlarını Tablo 1'de görüldüğü üzere iki kategoride toplamıştır.

Tablo 1. Okul dışı öğrenme ortamları

\begin{tabular}{cll}
\hline & Hayvanat Bahçeleri \\
& Botanik Bahçeleri \\
& Müzeler \\
& Bilim merkezleri \\
1. Non-formal ortamlar & Planetaryumlar \\
Okul/ Sınıf dışı Öğrenme & Sanayi Kuruluşları \\
Ortamları & Milli Parklar \\
& Akvaryumlar \\
& & Üniversite/Araştırma \\
& merkezleri \\
\hline & Oyun sahaları/Sokak \\
& 2. İnformal ortamlar & Mobil elektronik cihazlar \\
& Web 2 uygulamaları \\
& e- öğrenme \\
\hline
\end{tabular}

Müzeler, doğa tarihi müzeleri, hayvanat bahçeleri, planetaryumlar, botanik bahçeleri, üniversiteler, araştırma merkezleri, milli parklar, bilim merkezleri, sanayi kuruluşları ve okul bahçeleri gibi alanlar birer okul dışı öğrenme ortamıdırlar. Öğrenciler okul içinde 
öğrendikleri fen öğretimini okul dışı ortamlarda deneyimleme fırsatı elde edebilmektedirler (Türkmen, 2010).

Okul dışı ortamlarda kullanılabilecek en önemli derslerden biri fen bilimleri dersidir. Öğrenciler tarafından fen bilimleri dersi çok sevilmeyen ve zor anlaşılan bir ders olarak ifade edilmektedir (Kırıkkaya-Buluş, 2008). Fen bilimleri konuları günlük hayatta pek çok alanda karşılaşılabilecek olgu ve olaylara sahipken, bu olguları günlük hayatla ilişkilendirmeden öğretilmeye çalışmak onu sıkıcı ve zor bir ders yapabilmektedir. Bu anlamda okul dışı ortamların eğlenceli ve motive edici farklılıklarından faydalanılması gerekmektedir.

Öğretim süreçlerinde genellikle fen eğitimi okulda yapılan bir faaliyet olarak görülmektedir. Bu yüzden fen bilimleri öğretim programı içindeki olgu, kavram ve olayları günlük hayatla bağdaştırabilen fen okuryazarı birey sayısı oldukça azdır. Çünkü doğrudan gözlem yapma şansı olmayan öğrencilerden o durum ile ilgili açıklamalar üretmesi beklenmektedir. Böyle durumlarda çoğu zaman öğrencinin işini zorlaştırmakta ve onu bilgi edinmede ezbere yönlendirmektedir. Hâlbuki öğrencilerin daha geçerli ve güvenilir açıklamalar yapmaları, okullarda aldığı bilgilerin teorik çerçevelerini doğru bir biçimde anlayabilmeleri ile doğrudan ilişkilidir. Zihinsel alt yapısını teorik bilgi ile doğru bir biçimde yapılandıran öğrenci, öğrendiklerini hayatla bağdaştırdığı noktada daha kalıcı öğrenmeler oluşturabilmektedir. Ayrıca bilimsel okuryazar olan bireyden edindiği kuramsal bilgileri günlük hayatına yansıtabilen ve bu süreçte merak eden, araştıran, sorgulayan, yargıda bulunabilen bireyler olmaları beklenmektedir. Bunun yanında bireyin aldığı fen eğitimini yaşam şeklinde karşılığı olan tüm ortamlarda kullanılabileceği ilgiye, motivasyona, tutum ve becerilere sahip olmasıdır (Duruk, Akgün, Yılmaz, Özün, Aykut \& Tekin, 2018).

Okul dışı öğrenme ortamlarında gerçekleşen öğrenmeler konunun doğrudan deneyimlenmesini sağlamakla beraber disiplinler arası aktarımı ve üst düzey düşünme becerilerinin gelişimini de destekler (Ertaş, Şen \& Parmaksızoğlu, 2011). Bunlara ek olarak bilişsel, sosyal ve duyuşsal gelişimi ile beraber sözlü iletişim becerilerinin gelişimine, problem çözme becerilerine hatta kimlik oluşumuna da olumlu katkılar sunmaktadır (Bozdoğan, 2012; Duruk ve diğ., 2018). Okul dışı öğrenme ortamları insanların bilime karşı olumlu düşünceler geliştirmesine ve öğrenmeye yardımcı olma konusunda büyük bir potansiyele sahiptir. Dolayısıyla öğrenmenin hem bilişsel hem de duyuşsal eksenleri üzerinde bir etkisi olduğu anlamına gelir (Eshach, 2007). Okullarda iyi planlanmış okul dışı eğitimini sık düzenlemek önemli olacaktır. Çünkü sahada yapılan bu çalışmalar, küçük 
ölçekli uygulamaları ve gözlemleriyle, sınıfta yapılan öğretime göre daha etkilidir. Örneğin hayvanat bahçelerinde, botanik bahçelerinde, bilim parklarında, enerji parklarında, müzelerde veya araştırma kurumlarında öğrenme, öğrencilerin okulda bilim hakkında daha fazla şey öğrenmeye ilgisini de artırabilir (Uitto, Juuti, Lavonen \& Meisalo, 2006).

Okul dışı öğrenme ortamları öğretim programındaki olgu, kavram ve olaylar günlük hayatla bağdaştırabildiği için sosyobilimsel konuların farkındalı̆̆ı açısından da ideal ortamlar olabilmektedir. Sosyobilimsel konular yerel, ulusal veya uluslararası boyutta en başta bilim insanları olmak üzere toplumun pek çok kesiminde fikir ayrılıklarına neden olan, kişilerin karar vermekte zorlandığı, fayda zarar durumlarının tartışıldığı ve aynı zamanda sosyal boyutları olan bilimsel temelli konulardır (Ratcliffe \& Grace, 2003'den akt. Topaloğlu \& Kıyıc1, 2018). Dolayısıyla bir konunun sosyobilimsel bir anlam taşıması için; 1. Konunun bilimsel bir konu olması, 2. Toplumları ilgilendiren bir anlamı, sosyal bir önemi olması gerekir.

Organ bağışı ve organ nakli, Genetiği Değiştirilmiş Organizmalar (GDO), küresel iklim değişikliği, nükleer santraller, sürdürülebilir kalkınma ve çevre en çok bilinen sosyobilimsel konulardandır. Belirtilenlere benzer sosyobilimsel konular bilim ve teknolojinin değişmesi ve gelişmesine bağlı olarak etkisini günlük hayatımızda giderek artan şekilde göstermektedir. Dolayısıyla bu konuların yaşamın hatta geleceğin şekillenmesinde etkisi olabileceği savunulabilir. Bu yüzden fen öğretiminde fen okuryazarı olması hedeflenen bireylerin bu konular hakkında da fikir sahibi olması, fikirlerini ortaya koyması, bu konularla alakalı tartışabilmesi büyük önem arz etmektedir. Dolayısıyla okul dışı ortamlar bu yöndeki tartışmaların yapılabileceği ideal ortamlar sağlayabilmektedir.

Türkiye'de sıkça basın yayın organlarında yer alan Nükleer Enerji Santrali kurulumunun koşulları, çevresel getirileri, alınacak önlemler iken bir diğer konusu bor madeni yönünden zengin ülkemizde borun kullanım alanları ve önemidir. Yine aynı popülerlikte olan bir konu ise Türkiye'de maden ocakları, bu ocakların çalıştırma koşulları ve geleceğidir. $\mathrm{Bu}$ konular gibi toplumu ilgilendiren, üzerinde pek çok kesimin fikir yürütebileceği, sosyal önemi olan konularda daha yerinde bilgiler edinebilmek amaciyla bir enerji parkına ya da bir maden ocağına gezi düzenlenebilir. Bu sayede öğrencilerin okul dışındaki bilgi kaynaklarına ulaşması sağlanabilir. Örneğin öğrencinin enerji parkında göreceği nükleer reaktör maketi ya da hidroelektrik santral maketini incelemesi ile okulda 
öğrendiklerinin günlük hayat ile bağlantısını kolaylıkla kurmasını sağlayabilir (Ertaş, Şen \& Parmasızoğlu, 2011).

Okul dışı öğrenme ortamında planlı bir şekilde yapılacak olan etkinlikler öğrencilerin öğrenmelerini daha eğlenceli biçime dönüştürecek etkiye de sahiptirler (Noel, 2007'den akt. Bozdoğan \& Kavcı, 2016). Beş duyu organını kullanma fırsatı bulan bireyler farklı disiplinleri bir arada görerek daha kalıcı öğrenmeler edinebilirler (Tatar \& Bağrıyanık, 2012). Ayrıca okul dışı ortamlarda yapılan öğretim ile çocuklar toplumlaşma ve sosyalleşme fırsatı bulduklarından ilgili konu, mekân veya duruma yönelik daha fazla sorumluluk bilinci geliştirebilmektedirler (Demir, 2007). Öğrencilere işbirlikli öğrenme ortamları sağlaması ve yapılandırdıkları bilgileri birbirleri ile paylaşabilme imkânı sunması onların sosyalleşebilmelerine de katkı sağlar (Bozdoğan, 2012).

Sosyalleşebilme adına çok farklı canlı çeşitlerinin bir arada gözlenebileceği okul dışı ortamlardan biri olan botanik bahçeleri, dolaylı olarak da olsa sürdürülebilir kalkınmaya hizmet eden bir öğrenme ortamıdır. Gelecek nesillerin özellikle hammadde ve enerji ihtiyaçlarını göz önünde tutarak ona göre kalkınma modelleri oluşturulmasına sürdürülebilir kalkınma denir. Ekonomik ve sosyal yapının çevre ile etkileşimini bir bütün olarak değerlendirerek bugünün ve gelecek nesillerin kalkınmasının, hammadde ve enerji fırsatlarının adaletli olarak paylaşılması felsefesine dayanmaktadır (URL-1, 2019). Botanik bahçelerinde ekosistemlerin bugünü ve geleceği ile ilgili fikirler, görüşler, tartışmaların gerçekleşebilmesinin yanı sıra sosyal ve bilimsel farkındalıkların gelişmesi mümkün olabilmektedir.

Okul dışı öğrenme ortamlarını kullanan öğretmenlerin çok azının ön hazırlık yaptığı ve çoğunluğunun bu tür ortamlardan nasıl yararlanacağını bilmediği görülmektedir. Bu bağlamda okul dışı öğrenmelerde dikkat edilecek en önemli unsurlardan bir tanesi doğru planlamadır. Yetersiz yapılmış ya da yapılmamış hazırlıklar okul dışı etkinliğe olan ilgiyi ve sonrasında etkinlikten elde edilecek verimi önemli oranda azaltmaktadır (Morag \& Tal, 2012; Morentin \& Guisasola, 2015'ten akt Duruk ve diğ., 2018).

Alanyazın incelendiğinde pek çok faydasına rağmen okul dışı ortamların eğitimciler tarafından çok da fazla kullanılmadı̆̆ı görülmektedir (Saraç, 2017; Tatar \& Bağrıyanık, 2012; Türkmen, 2010). Bu duruma gerekçe olarak belirtilenler aşağıda maddeler halinde sunulmuştur. 
- Öğretmenlerin okul dışı ortam gezileri ile alakalı geziyi gerçekleştirebilecek düzeyde bilgiye sahip olmamaları (Güler, 2009),

- Eksik özyeterlilik ve kaygı yaşamaları (Bozdoğan, 2008),

- Gezi alanı ile ilgili rehberlik yapamama (Saraç, 2017),

- Öğrenci kontrolünün zorluğu (Duruk ve diğ., 2018),

- Derslerin sınıf içinde daha verimli işleneceğine olan inanç ve kaygı (Duruk ve diğ., 2018),

- Sağlık ve güvenlik riski (Bozdoğan, 2008),

- Kaynak eksikliği (Bozdoğan, 2008),

- Öğretim programında yer alan konuların zamanında yetiştirilmesine ilişkin endişe (Bozdoğan, 2008),

- Bürokratik işler ve kalabalık okullarda uygulanma zorluğu (Bozdoğan, 2008) vb.

$\mathrm{Bu}$ ve benzeri sebepler okul dişı ortam gezilerinin düzenlenmesine veya hazırlık aşamalarına olumsuz yansımaktadırlar. Özellikle içeriğin yetiştirilmesini öncelikli hedef sayan öğretmenler okul dışı etkinlikleri iş yükünü artıran faaliyetler olarak kabul etmektedirler. Oysaki bu kazanımları gezi sırasında doğrudan kazandırabilen etkinlikler gerekmektedir (Bakioğlu \& Karamustafaoğlu, 2017). Ayrıca hazırlanan etkinliklerin ve planların yararlı olabilmesi için etkisi yüksek olan öğretim stratejilerine ihtiyaç duyulmaktadır (Pasquier \& Narguizian, 2006'dan akt. Duruk ve diğ., 2018).

\section{Araștırmanın Amacı}

$\mathrm{Bu}$ araştırmanın amacı 5. sınıf fen bilimleri dersinde kullanılabilecek Sürdürülebilir Çevre konusunda örnek bir okul dişı öğrenme ortamı olan botanik bahçesine gezi uygulaması tasarlamak, yürütmek ve öğrenciler üzerindeki yansımalarını incelemektir.

\section{Araştırmanın Önemi}

Çalışma 2023 eğitim vizyonu çerçevesinde belirlenen hedeflere yönelik bir çalışma olup 2018 Fen Bilimleri Öğretim Programında belirlenen kazanımlar dikkate alınarak yapılmıştır. Dolayısıyla çalışma 2023 eğitim vizyonu hedeflerine ulaşma noktasında örnek bir çalışmadır. 5. sınıf "İnsan ve Çevre" ünitesindeki kazanımlara (MEB, 2018) göre etkinlikler hazırlanmıştır. 


\section{Yöntem}

$\mathrm{Bu}$ bölümde araştırma modeli, çalışma grubu ve gezi süreci hakkında bilgi verilmiştir.

Araştırma Modeli

Çalışmada nitel araştırma yöntemlerinden durum çalışması kullanılmıştır. Bu yöntemin en büyük özelliği bir veya birden fazla durumun derinlemesine incelenebilmesidir. Buna göre bir durumu etkileyen etkenler araştırılır. Durumu nasıl etkilediği ve durumdan nasıl etkilendiği ile ilgilenir (Yıldırım \& Şimşek, 2008). Çalışmada okul dışı ortamlara gerçekleştirilecek bir gezisinin nasıl düzenleneceği ile ilgili bilgi verilmesi ve gerçekleştirilen gezinin katılımcılar üzerindeki etkisini incelemek için bu yöntem seçilmiştir. Bu kapsamda Ata Botanik Bahçesine düzenlenen geziye 5. sınıf öğrencileri ile gidilerek gezi öncesi ve sonrası Sürdürülebilir Çevre Bilinci Ölçeği uygulanmıştır. Ayrıca, gezi dönüşünde öğrencilerin gezi hakkındaki düşünceleri alınmıştır.

\section{Çalışma Grubu}

Araştırma 2018-2019 eğitim-öğretim yılı bahar döneminde Ağrı ili Merkez ilçesinde bir ortaokulda öğrenim görmekte olan 5. sınıf 32 öğrenci ile yürütülmüştür. Geziye katılan öğrenciler daha önce botanik bahçesine gitmemişlerdir.

Verilerin toplanmas//Veri toplama aracı

Çalışmada 2018 Fen Bilimleri Öğretim Programında yer alan 5. sınıf “İnsan ve Çevre” ünitesine ait kazanımlara göre etkinlikler hazırlanmıştır.

Yapılan gezi ayrıntılı olarak planlanmış ve çalışmada kullanılmak üzere etkinlik kâğıtları hazırlanmıştır. Gezi boyunca yapılan çalışmalar Tablo 2' de belirtilmiştir.

Tablo 2: Gezi ile ilgili yapılan çalışmalar

\section{Gezi öncesi}

- Broşür: Botanik Bahçesi Nedir? (Ek 1)

- Broşür: ATA Botanik Bahçesi Tanitımı (Ek 2)

\section{Gezi sürecinde}

- Canlı Tanıma Formu (Ek 3)

- Ekosistem Etkinliği (Ek 4)

- Bak-Bul- Eşleştir Etkinlik Kâğıdı (Ek 5)

- Evvel Zaman İçinde Etkinlik Kâğıdı (Ek 6) 
Veri toplama aracı olarak Derman (2013)'ün geliştirmiş olduğu “Sürdürülebilir Çevre Bilinci Ölçeği" kullanılmıştır. 10 maddeden oluşan bu ölçek, Küresel çevre sorunlarına duyarlı olma, Doğal kaynakları koruma, Doğal hayatı koruma, Endüstriyel ve evsel atık yönetimini destekleme ve Doğanın kendini yenilemesine katkıda bulunma göstergelerini içermektedir. Ölçekte her bir örnek durumu belirten maddeler için "c şıkkı, istenen (3 puan), b şıkkı kısmen istenen (2 puan) ve a şıkkı istenmeyen (1 puan)" şeklinde 3 düzeyde ortaya koyabilecekleri tepkileri ifade eden seçenekler yazılmıştır (Derman, 2013). Cronbach $\alpha$ değeri 0.87 olan ölçeğin geliştirilmesi aşamasında alanyazından yararlanılarak belirlenen göstergelere göre dağılımı Tablo 3'te verilmiştir.

Tablo 3: Maddelerin göstergelere göre dağılımı

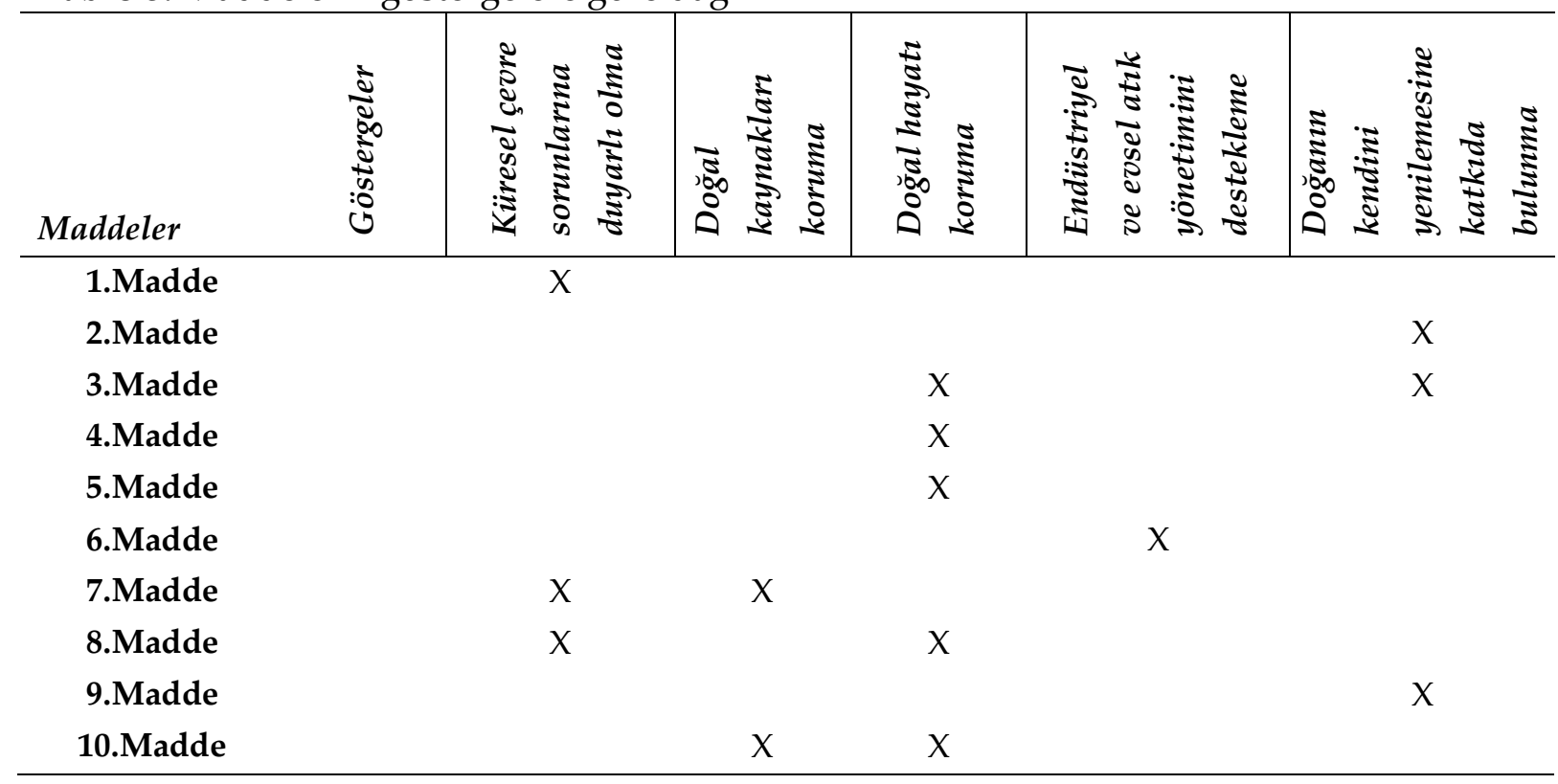

Göstergelerin ilişkili olduğu kazanımlar Tablo 4'te verilmiştir.

Tablo 4: Göstergelerin ilişkili olduğu kazanımlar

\begin{tabular}{l|l}
\hline Göstergeler & Illişkilendirildiği Kazanım \\
\hline a. Küresel çevre sorunlarına duyarlı olma & F.5.6.2.2 \\
b. Doğal kaynakları koruma & F.5.6.1.1. \\
c. Doğal hayatı koruma & F.5.6.1.2. \\
d. Endüstriyel ve evsel atık yönetimini & F.5.6.2.4. \\
destekleme & \\
e. Doğanın kendini yenilemesine katkıda & F.5.6.2.3. \\
bulunma & \\
\hline
\end{tabular}


Ayrıca, gezi dönüşünde öğrencilerin gezi hakkındaki düşünceleri yapılandırılmamış bir grup mülakatı çerçevesinde “Gerçekleştirdiğimiz gezi hakkında genel olarak neler düşünüyorsunuz?" şeklinde soru ile alınmaya çalışılmıştır.

\section{Uygulama Süreci}

Uygulama kapsamında öğrencilerin sürdürülebilir çevre sosyobilimsel konusu ile "İnsan ve Çevre" ünitesinin konu ve kavramlarını doğal ortamında gözlemleyip değerlendirme ve doğrudan ilk elden bilgi alabilmeleri amacıyla okul dışı öğrenme ortamlarından biri olan Ata Botanik Bahçesine gezi düzenlenmiştir. Gerçekleştirilen gezi öncesinde literatür taraması yapılarak araştırma kapsamındaki sosyobilimsel konu belirlenmiştir. Belirlenen sosyobilimsel konu ile ilgili öğretim programındaki mevcut kazanımlar incelenmiş ve okul dışı öğrenme etkinliğini gerçekleştirebilmek için botanik bahçesi gezisi planlanmıştır.

Derste yürütülecek olan konu ile ilişkilendirilerek uygun bir ders planı hazırlanmıştır. Daha sonra ziyarete gidilecek olan botanik bahçesine gezinin yapılacağı gün ve saat belirtilerek randevu alınmış, geziye katılacak öğrenci sayısı belirtilmiştir. Yapılan planlama çerçevesinde öğrenci ve yetkililer gidiş dönüş yolu, süresi, ulaşım araçları, hareket saatleri ve gezi ücretleri konusunda bilgilendirilmiştir. Öğrenciye aktarılacak olan içerik hazırlanmış ve yapılacak olan gezi ile ilgili gerekli izinler alınmıştır. Gezi planlanmasının sonrasında yapılacak araştırmada kullanılmak üzere hazırlanan ve Tablo 2'de gösterilen etkinliklerin, içerik ve kapsam geçerliliğini sağlamak amacıyla alan eğitiminde uzman iki öğretim üyesinin görüşlerinden faydalanılmıştır. Veri toplama aracı olarak Derman (2013)'ün geliştirmiş olduğu “Sürdürülebilir Çevre Bilinci Ölçeği” izin alınarak ön test ve son test olarak uygulanmıştır.

\section{Gezi süreci}

- Gezi 4 Mayıs 2019 Cumartesi günü saat 8.30'da Ağrídan otobüsle hareket edilerek başlanmiştır.

- Gezi öncesi tanıtım broşürleri (Ek 1; Ek 2) otobüslerde öğrencilere dağıtılmış ve okumaları sağlanmıştır. Sürdürülebilir çevre ölçeği ön test olarak uygulanmıştır.

- 11.10 itibari ile Erzurum Ata Botanik Bahçesine varılmıştır. Öğrencilere kısaca botanik bahçesi tanıtılmıştır. Canlı tanıma formu (Ek 3) dağıtılmış, etraflarında gördükleri bitki ve hayvanlar tanıtılmıştır. Saat 13.00'a kadar beraber gezilmiştir. 
- Etkinliklere 13.00-14.00 arası öğle yemeği için mola verilmiş, yemek sonrası etkinliklere devam edilmiştir.

- 14.00 'dan sonra $30 \mathrm{dk}$. serbest zaman dilimi verilmiştir.

- 14.30 'dan sonra diğer etkinlikler uygulanmıştır (Ek 5; Ek 6).

- Ata Botanik Bahçesine yapılan gezi kapsamında; Botanik Bahçesi nedir? Ata Botanik Bahçesinin Özellikleri nelerdir ve hangi canlı türleri vardır? Endemik tür, Nesli tükenme tehlikesi altında olan canlılar, Çevreyi koruma ve güzelleştirme, İnsan ve çevre etkileşimi, Sürdürülebilir çevre, mahalli ve küresel çevre sorunları konuları işlenmiş, bu alanlarda bilgiler verilmiştir. Öğrenciler hem yetkili kişiye merak ettiklerini sormuş hem de eğlenerek öğrenme sağlamışlardır.

- Etkinlikler ortalama 4 saat içinde gerçekleştirilmiştir.

- Gezi sonunda topluca fotoğraf çekilmiştir.

- Saat 16.30 itibari ile dönüş için hareket edilerek başlangiç konumu Ağrı'ya 19.00' da varılmıştır.

- Dönüş yolunda sürdürülebilir çevre ölçeği son test olarak uygulanmıştır.

Dönüş yolunda öğrencilerin gezi hakkındaki düşünceleri alınmıştır.

\section{Bulgular}

Bu bölümde Sürdürülebilir Çevre Bilinci Ölçeğinden ve öğrencilerin görüşlerinden elde edilen bulgulara yer verilmiştir. Sürdürülebilir Çevre Bilinci Ölçeği 5. sınıf öğrencilerine ön test ve son test olarak uygulanmıştır. Ön test ve son test puanlarının istatistiksel analizinde bağımlı örneklemler için t-testi kullanılmış ve analiz sonuçları Tablo 5'te gösterilmiştir.

Tablo 5. Sürdürülebilir çevre bilinci ölçeği analiz sonuçları

\begin{tabular}{cccccccc}
\hline Sürdürülebilir & & $\mathbf{N}$ & $\mathbf{X}$ & $\mathbf{S S}$ & $\mathbf{S d}$ & $\mathbf{t}$ & $\mathbf{P}$ \\
\hline Çevre Bilinci & Ön test & 32 & 26,09 & 12,6 & \multirow{2}{*}{2,375} & $-2,82$ & $.008^{*}$ \\
Ölçeği & Son test & 32 & 27,28 & 23,3 & & & \\
\hline
\end{tabular}

Tablo 5'te sunulan veriler incelendiğinde öğrencilerinin ön test puan ortalamasının 26,09 ve son-test puan ortalamasının 27,28 olduğu görülmektedir. Öğrencilerin ön-test ve son-test puanları arasında istatiksel anlamda bir farklılık vardır ( $\mathrm{t}=-2,82 ; \mathrm{p}<.05)$. Bu farklılık son test puanları lehine olarak belirlenmiştir. Botanik bahçesine yapılan gezinin öğrencilerin çevre bilincini artırmada etkili olduğu söylenebilir. 
Tablo 6. Sürdürülebilir çevre bilinci düzeyine ilişkin yüzde ve frekanslar

\begin{tabular}{|c|c|c|c|c|c|}
\hline \multirow{2}{*}{\multicolumn{2}{|c|}{ Maddeler }} & \multicolumn{2}{|c|}{ Ön test } & \multicolumn{2}{|c|}{ Son test } \\
\hline & & $f$ & $\%$ & $f$ & $\%$ \\
\hline \multirow{5}{*}{ Madde 1} & $a$ & & & & \\
\hline & (Yetersiz) & 0 & 0 & 0 & 0 \\
\hline & $\mathrm{b}$ (Kısmen & & & & \\
\hline & yeterli) & 7 & 21,9 & 6 & 18,8 \\
\hline & c (Yeterli) & 25 & 78,1 & 26 & 81,3 \\
\hline \multirow{3}{*}{ Madde 2} & a (Yetersiz) & 0 & 0 & 1 & 3,1 \\
\hline & $\begin{array}{l}\mathrm{b} \text { (Kısmen } \\
\text { yeterli) }\end{array}$ & 13 & 40,6 & 6 & 18,8 \\
\hline & c (Yeterli) & 19 & 59,4 & 25 & 78,1 \\
\hline \multirow{4}{*}{ Madde 3} & a (Yetersiz) & 3 & 9,4 & 0 & 0 \\
\hline & b (Kısmen & & & & \\
\hline & yeterli) & 4 & 12,5 & 6 & 18,8 \\
\hline & c (Yeterli) & 25 & 78,1 & 26 & 81,3 \\
\hline \multirow{4}{*}{ Madde 4} & a (Yetersiz) & 3 & 9,4 & 3 & 9,4 \\
\hline & b (Kismen & & & & \\
\hline & yeterli) & 15 & 46,9 & 9 & 28,1 \\
\hline & c (Yeterli) & 14 & 43,8 & 20 & 62,5 \\
\hline \multirow{3}{*}{ Madde 5} & a (Yetersiz) & 5 & 15,6 & 3 & 9,4 \\
\hline & $\begin{array}{l}\mathrm{b}(\mathrm{K} \text { ismen } \\
\text { yeterli) }\end{array}$ & 11 & 34,4 & 13 & 40,6 \\
\hline & c (Yeterli) & 16 & 50 & 16 & 50 \\
\hline \multirow{3}{*}{ Madde 6} & a (Yetersiz) & 1 & 3,1 & 1 & 3,1 \\
\hline & $\begin{array}{l}\mathrm{b}(\mathrm{K} 1 \mathrm{smen} \\
\text { yeterli) }\end{array}$ & 5 & 15,6 & 5 & 15,6 \\
\hline & c (Yeterli) & 26 & 81,3 & 26 & 81,3 \\
\hline \multirow{3}{*}{ Madde 7} & a (Yetersiz) & 2 & 6,3 & 0 & 0 \\
\hline & $\begin{array}{l}\mathrm{b}(\text { Kismen } \\
\text { yeterli) }\end{array}$ & 4 & 12,5 & 4 & 12,5 \\
\hline & c (Yeterli) & 26 & 81,3 & 28 & 87,5 \\
\hline \multirow{3}{*}{ Madde 8} & a (Yetersiz) & 1 & 3,1 & 0 & 0 \\
\hline & $\begin{array}{l}\mathrm{b}(\text { Kismen } \\
\text { yeterli) }\end{array}$ & 6 & 18,8 & 6 & 18,8 \\
\hline & c (Yeterli) & 25 & 78,1 & 26 & 81,3 \\
\hline \multirow{3}{*}{ Madde 9} & a (Yetersiz) & 2 & 6,3 & 0 & 0 \\
\hline & $\begin{array}{l}\mathrm{b}(\text { Kismen } \\
\text { yeterli) }\end{array}$ & 14 & 43,8 & 11 & 34,4 \\
\hline & c (Yeterli) & 16 & 50 & 21 & 65,6 \\
\hline \multirow{3}{*}{ Madde 10} & a (Yetersiz) & 3 & 9,4 & 0 & 0 \\
\hline & $\begin{array}{l}\mathrm{b}(\text { Kismen } \\
\text { yeterli) }\end{array}$ & 6 & 18,8 & 5 & 15,6 \\
\hline & c (Yeterli) & 23 & 71,9 & 27 & 84,4 \\
\hline
\end{tabular}


Tablo 6'da sunulan verilere göre öğrencilerin her bir maddeye verdikleri "yeterli" cevabı ön teste $\% 43,8$ ile $\% 81,3$; son testte ise $\% 50$ ile $\% 87,5$ arasında olduğu görülmektedir. İlaveten son testte ön teste göre her maddeye verilen "yeterli" cevap yüzdelerinin daha yüksek olduğu görülmektedir. Bunun yanı sıra öğrencilerin Tablo 6' da verilen her bir madde için işaretledikleri seçeneğe dair açılamaları da incelenmiştir. Açıklamalar incelendiğinde sürdürülebilir çevre bilincine sahip olduklarını işaret eden gerekçeler Tablo $7^{\prime}$ de gösterilmiştir.

Tablo 7. Sürdürülebilir çevre bilinci işaret eden frekans tablosu

\begin{tabular}{lc}
\hline Sürdürülebilir Çevre Bilincine İşaret Eden Cümleler & $\mathrm{f}$ \\
\hline $\begin{array}{l}\text { Çevre sorunlarının oluşmasında ve önlenmesinde kendi payına düşen sorumluluğun } \\
\text { farkında olma }\end{array}$ & $\mathbf{2 6}$ \\
\hline Doğanın canlı ve canlı olmayan varlıklardan oluşan bir dengeye sahip olduğunu bilme & $\mathbf{2 7}$ \\
\hline Doğayı her haliyle sevme & 23 \\
\hline Doğa ile iç içe olmaktan zevk alma & 23 \\
\hline Doğal çevreyi korumak için gereken ne varsa yapmayı isteme & $\mathbf{2 6}$ \\
\hline
\end{tabular}

Tablo 7'de sunulan verilerin aksine öğrencilerin yeterli çevre bilinci düzeyine sahip olmadıklarına işaret eden gerekçeler Tablo 8' de sunulmuştur.

Tablo 8. Sürdürülebilir çevre bilincine sahip olunmadığını işaret eden frekans tablosu

\begin{tabular}{ll}
\hline Sürdürülebilir Çevre Bilincine Sahip Olunmadığını İşaret Eden Cümleler & $\mathrm{f}$ \\
\hline Hayvanları sevmeme & $\mathbf{2}$ \\
\hline Hayvanlardan korkma & $\mathbf{3}$ \\
\hline Hayvanlarla aynı ortamı paylaşmayı istememe & $\mathbf{1}$ \\
\hline Alerji olma ve hastalık kapma korkusu & $\mathbf{1}$ \\
\hline Etraflarında doğa ile iç içe alanların olmayışı & $\mathbf{2}$ \\
\hline
\end{tabular}

Gezi sonrası oldukça mutlu oldukları gözlemlenen öğrencilerle dönüş yolunda gerçekleştirilen yapılandırılmamış mülakatta; kendilerine yöneltilen soruya, Ö1, Ö2, Ö3 ... olarak kodlanan öğrencilerin memnuniyetlerini ifade eden cümlelerden bazı örnekler aşağıda sunulmuştur.

Ö1: Öğretmenim iyi ki geldik, ben başka zaman bir tavus kuşu göremeyebilirdim.

Ö2: Öğretmenim burası çok temiz, çok güzel... yaz aylarında eminim çok daha güzel olur.

Ö3: Öğretmenim burada çok güzel çiçekler var, annem için bol bol fotoğraf çektim...

Ö4: ..... bu çiçeklerden eve götürebilir miyiz?..

Ö5: .... annemin içtiği ıhlamur çayının ağacını görmek çok tuhaf ...

Ö6: ... burada survivorkids var! Öğretmenim siz Acun olun biz de yarışalım! Harika ...

Ö7: Annem, babam ve kardeşlerimle beraber tekrar geleceğim... 
Ö8: Hayatımda ilk defa bir tarşana dokundum! Hiç de korkmadım.

Ö9: Burada hem insanlar hem hayvanlar mutlu... keşke evimizin etrafı da böyle olsaydı...

Ö10: ... aaa mavi çam ağacı gördüm! (mavi ladin)

Ö11: ... Bizi bu güzel yere getirdiğiniz için çok teşekkür ederiz öğretmenim...

Okul dışı öğrenme ortamlarının öğrencilerin sosyobilimsel konularla ilişkili kazanımlarının yanında öğretimi daha eğlenceli biçime dönüştürecek etkiye sahip olduğu, onların moral ve motivasyonlarına da ciddi katkılar yaptığı öğrencilerin kendi ifade ettikleri cümlelerinden de anlaşılmaktadır.

\section{Tartışma}

Araştırmada kullanılan Sürdürülebilir Çevre Bilinci Ölçeğine ait maddelerin analizine bakıldığında, 5. maddede yer alan doğal hayatı koruma göstergesi olarak hazırlanan “Evinize oldukça yakın bir yerde içinde pek çok hayvan türünün yaşadığı bir sazlık bulunmaktadır. Ancak özellikle yaz aylarında sazlık nedeniyle çok fazla sinek bu alana gelmektedir. Bir inşaat firması sazlığın bulunduğu yere bir alışveriş merkezi yapmak istemektedir. Ancak mahallenizdeki bazı komşularınız buna karşı çıkmaktadır. Eğer senin fikrini sorsalardı;" sorusuna son testte verilen cevaplarda herhangi bir değişikliğin olmadığı, istatistiksel olarak ihmal edilebilecek sayıda çok az cevabın istenmeyenden kısmen istenene doğru değiştiği görülmüştür. Bunun sebebinin soruda sazlık alan sebebi ile çok fazla sinek oluşumundan bahsetmesi, durumu istenmeyen bir hal gibi göstermiş olduğu düşünülmektedir.

Ölçeğin 6. maddesinde de bulunan “Öğretmenin sınıfınızda asılı bulunan duvar saatinin pilinin bittiğini söyledi ve senden yeni bir pil takmanı rica etti. Saatten çıkan eski pili; a) Hemen sınıftaki çöpe atarsın. b) Varsa atık pil toplama kutusuna atarsın, yoksa çöpe atarsın. c) Varsa atık pil toplama kutusuna atarsın, yoksa konulması için okul müdürünüzle konuşursun." şeklinde ki soruda ön teste göre son testte istenen cevap verenlerin yüzdelerinin aynı kaldığ1 görülmüştür. \%81,3'lük kısmın istenen düzey cevap vermiştir. Diğer öğrencilerin cevaplarının değişmemesinde çekingenlik duygusunun ağır bastığı düşünülmektedir. Atık pil kutusu olmaması halinde okul müdürü ile konuşma konusunda çekingenlik göstermiş olmaları muhtemeldir. Diğer tüm cevaplarda son test lehine bir artış oluğu görülmüştür. Botanik bahçesi ziyareti sırasında ortamın güzelliğinden etkilenen 
öğrencilerin çevreye karşı olumlu bilinç kazandıkları düşüncesi oluşmuştur. Bu düşünceyi Çavuş, Topsakal ve Öztuna Kaplan (2013) çalışmaları da destekler niteliktedir.

Öğrencilerin gezi öncesi oldukça heyecanlı oldukları gözlenmiştir. Pek çoğu ilk defa ailesinden ayrı arkadaşları ile beraber il dışına çıkmış olmanın kendilerine güven verdiğini dile getirmiştir. Bu heyecan ve güven onları öğrenmeye daha da açık hale getirdiği savunulabilir (Braund \& Reiss'den akt., Sontay, Tutar \& Karamustafaoğlu, 2016). Gezi sonrasında memnuniyet ifadelerinden gezinin etkileyici olduğu ve çevreye karşı daha fazla bilinç kazandıkları düşünülmektedir. Özellikle doğal güzelliklerin sonraki nesilleri düşünerek koruma gerekliliği üzerinde konuşulmuş, doğaya zarar veren insan etkenleri üzerine tartışmalar yapılmıştır. Tartışmalar sonunda tüm insanların isterlerse hem doğasever olabilecekleri hem de doğayı koruyarak teknolojik ilerlemeler yapabilecekleri sonucuna varılmıştır. Çevre sorunlarının bugünü ve geleceği ciddi şekilde tehdit etmemesi için önlemler alınması gerektiği üzerinde durulmuştur. Öğrenciler bu konuda sorumluluk almak istediklerini belirterek kampanyalar düzenleyebileceklerini söylemişlerdir. Gezi sonrası okulda doğal çevrenin korunması, canlı çeşitliliği ve atık maddelerin kaynağında ayrıştırılması konusunda diğer 5. sınıflara bilgi vermek için örgütlenip küçük broşürler hazırlamışlardır. Ayrıca sınıfın büyük bir çoğunluğu aileleri ile birlikte bahçelerine ağaç dikmişlerdir. Sürdürülebilir çevre konusunda sorumluluk almak istemeleri ve çevrelerini tıpkı botanik bahçesi gibi görmek istemeleri botanik bahçesi gezisinden etkilenmelerine bağlanabilir. Nitekim Altıntaş (2014)'ın bir çalışması, okul dışı öğrenme ortamındaki öğrenme durumlarına ilişkin kişisel algıların olumlu yönde olduğunu belirlemesi bu durumu desteklemektedir.

Gezi sonrasında botanik bahçesi ile ilgili sorulan sorulara doyurucu ve detaylı bilgi verdikleri görülmüştür. Bu durumdan okul dışı ortamlarda öğrenmenin daha kolay ve kısa sürede gerçekleştiği sonucunu çıkarılabilir (Sontay, Tutar \& Karamustafaoğlu, 2016). Ancak resimlerde görebileceği canlıları bizzat yakından görme fırsatı edinen öğrencilerin öğrendikleri bilgileri daha rahat, daha kolay, daha kısa sürede ve daha eğlenerek öğrenmeleri daha verimli öğrenme gerçekleştirmiştir (Bishop, 2003'den akt., Bozdoğan ve Ustaoğlu, 2016).

Türkmen, Topkaç ve Atasayar Yamık (2016) çalışmasında öğrenciler botanik bahçesinde kısıtlanarak ve yönlendirilerek gezdirilmiş, bunun sonucu olarak öğrenciler oldukça sıkıldıklarını hatta dışarı çıkmak istediklerini belirtmişlerdir. Daha özgürce 
gezebildikleri doğa müzesinde ise hem daha çok eğlendiklerini hem de daha şey öğrendiklerini belirtmişlerdir. İlgili çalışmada öğrencilerin kısıtlandıkları ortamdan bilgi elde edemedikleri ortaya konulmuştur. Bu araştırmada ise yukarıda belirtilen çalışmanın aksine öğrencilerin fazlasıyla eğlendikleri ve keyifli zaman geçirerek öğrendikleri bir öğrenme ortamı oluştuğundan hedeflenen amaçlara ulaşıldı ğı düşünülmektedir.

Ayrıca, bu araştırmada öğrencilere doğayla iç-içe yapılan bir okul dışı öğrenmenin kendilerine sosyal değerler katma deneyimi yaşattığı, doğa sevgisi kazandırdığı, bahçe gibi bitkilerin yoğun olduğu yerlere karşı daha korumacı bir bilincin oluştuğu kanaati uyanmıştır. Bu kanaatini Var ve Karaşah (2010) bir çalışmasında botanik bahçelerinin kullanıcılara sağladığı eğitsel ve rekreatif imkânlarını araştırmış botanik bahçelerinin yararlarına değinmiş özellikle küçük yaşlarda doğa sevgisinin ve bitki koruma bilincinin oluşmasında yararlı olduğunu savunması destekler niteliktedir. İnsanların doğaya karşı pozitif tutum sergilemelerine etkisi olduğunun belirtildiği çalışmada, bireylerin sosyal değerleri etkileyen deneyimler kazandığını savunması çok önemlidir.

\section{Sonuçlar}

Yapılan çalışmada öğrencilerin birinci elden öğrenmeler gerçekleştirerek insan ve çevre ilişkilerini anlama ve sürdürülebilir çevre bilinci oluşturmada botanik bahçesine düzenlenen gezinin etkisi incelenmiştir. Gezi öncesinde ve sonrasında uygulanan Sürdürülebilir Çevre Bilinci Ölçeğinden elde edilen verilerin analizinde botanik bahçesine yapılan gezinin öğrencilerin çevre bilincini artırmada etkili olduğu sonucuna varılmıştır.

Gerçekleştirilen gezi etkinliği sonunda öğrencilerin Sürdürülebilir Çevre Bilinci Ölçeğinde her bir madde için ayrıntılı analizlerin de yüksek oranda çevre bilincine sahip olduklarını işaret eden bulgulara da ulaşılmıştır. Çevre sorunlarının oluşmasında ve önlenmesinde kendi payına düşen sorumluluğun farkında olma, doğanın canlı ve canlı olmayan varlıklardan oluşan bir dengeye sahip olduğunu bilme, doğayı her haliyle sevme, doğa ile iç içe olmaktan zevk alma, doğal çevreyi korumak için gereken ne varsa yapmayı isteme temalarında cümlelerin sıklıkla kullanıldığı tespit edilmiştir. Bu tespitlere göre öğrencilerin botanik bahçesi gezisinden etkilendikleri ve çevre bilinci duyarlılı̆̆ına sahip oldukları sonucuna varılabilir.

Ölçeğe ait maddelere verilen aynı açıklamalar incelendiğinde az sayıda da olsa hayvanları sevmeme, hayvanlardan korkma, hayvanlarla aynı ortamı paylaşmayı istememe, 
alerji olma ve hastalık kapma korkusu, etraflarında doğa ile iç içe alanların olmayışı temalarında cümlelere rastlanmıştır. Bu temalardaki sebeplerden dolayı az sayıda öğrencinin yeterli çevre bilinci duyarlılığı oluşmadığı sonucu çıkarılabilir.

Gezi öncesi öğrencilerin oldukça heyecanlı ve mutlu oldukları görülmüştür. Gezi sırasında bol bol fotoğraf çektiren öğrenciler botanik bahçesinde olmaktan duydukları mutluluğu çeşitli şekillerde ifade etmişlerdir. Bu ifadelerden öğrencilerin gezinin tüm sürecinden memnun oldukları sonucuna ulaşılabilir.

\section{Öneriler}

Yapılan çalışma kapsamında okul dışı etkinliklerin doğru ve etkili yapılabilmesi adına aşağıdaki önerilerde bulunulmuştur.

- 2023 Eğitim vizyonunda okul dışı öğrenme ortamları ile ilgili belirlenen hedeflere ulaşmak adına benzer çalışmalar yapılabilir.

- Öğrencilerin doğa sevgisi kazanmalarını sağlayacak deneyimler elde edebilmeleri için planlı okul dışı öğrenme ortamlarına geziler düzenlenebilir.

- Aynı sınıf düzeyinde Canlılar Dünyası ünitesi kapsamında kazanımlara yönelik farklı geziler düzenlenebilir.

- Botanik bahçelerine karşı öğrencilerde ilgi uyandırılması için öğretim programı ile ilişkilendirilecek geziler planlanabilir.

- Hayvanat bahçesi, milli parklar gibi canlı ve çevre odaklı öğrenme alanlarında benzer araştırmalar yürütülebilir.

\section{Kaynaklar}

Altıntaş, F., (2014). Doğa ve topră̆a yönelik hazırlanan informal öğrenme ortamının ilköğretim öğrencileri üzerine etkileri (Yüksek Lisans Tezi). YÖK Ulusal Tez Merkezi veri tabanından edinildi. (Tez No. 363230)

Bakioğlu, B. \& Karamustafaoğlu, O. (2017). A study on developing a guide material for science classes supported by out-of-school learning. Universal Journal of Educational Research, 5(5), 773-786.

Bozdoğan, A. E. \& Kavcı, A. (2016). Sınıf dışı öğretim etkinliklerinin ortaokul öğrencilerinin fen bilimleri dersindeki akademik başarılarına etkisi. Gazi Ĕ̆itim Bilimleri Dergisi, 2(1), 13-30.

Bozdoğan, A. E. \& Ustaoğlu, F. (2016). Planetaryumların öğretim potansiyeli hakkında fen bilimleri öğretmen adaylarının görüşleri. Part B: Türk Fen Ĕ̆itimi Dergisi, 13(1), 38-49. 
Bozdoğan, A. E. (2008). Fen bilgisi öğretmen adaylarının bilim merkezlerini fen öğretimi açısından değerlendirilmesi: Feza Gürsoy bilim merkezi örneği. Uludă̆ Ĕ̆gitim Fakültesi Dergisi, 21(1), 19-41.

Bozdoğan, A. E. (2012). Eğitim amaçlı gezilerin planlanmasına ilişkin fen bilgisi öğretmen adaylarının uygulamaları: Altı farklı alan gezisinin değerlendirilmesi. Kuram ve Uygulamada Eğitim Bilimleri, 12(2), 1049-1072.

Çavuş, R., Topsakal, Ü. U., \& Kaplan, A. Ö. (2013). İnformal öğrenme ortamlarının çevre bilinci kazandırmasına ilişkin öğretmen görüşleri: Kocaeli bilgi evleri örneği. Pegem Eğitim ve Öğretim Dergisi, 3(1), 15-26.

Demir, M. K. (2007). Sınıf öğretmeni adaylarının gözlem gezisi yöntemine bakış açılarının incelenmesi. Gazi Eğitim Fakültesi Dergisi, 27(3), 83-98.

Derman, İ. (2013). Farklı başarı düzeylerindeki okullarda 9 ve 12. Sını öğrencilerinin ekosisteme ilişkin öğrenme düzeyleri ve sürdürülebilir çevre bilinci ile ilişkisi (Yüksek Lisans Tezi). YÖK Ulusal Tez Merkezi veri tabanından edinildi. (Tez No. 339097)

Duruk, Ü., Akgün, A., Yılmaz, N., Özün, S., Aykut, N. \& Tekin, S. (2018). Fen bilgisi öğretmen adaylarının okul dışı öğrenme ortamlarındaki deneyimlerine ilişkin görüşleri. Diyalektolog Ulusal Sosyal Bilimler Dergisi, 18, 315-332.

Ertaş, H., Şen, A. İ., \& Parmaksızoğlu, A. (2011). Okul dışı bilimsel etkinliklerin 9. sınıf öğrencilerinin enerji konusunu günlük hayatla ilişkilendirme düzeyine etkisi. Necatibey Ĕğitim Fakültesi Elektronik Fen ve Matematik Ĕ̆itimi Dergisi, 5(2), 178-198.

Erten, Z., \& Taşçı, G. (2016). Fen bilgisi dersine yönelik okul dışı öğrenme ortamları etkinliklerinin geliştirilmesi ve öğrencilerin bilimsel süreç becerilerine etkisinin değerlendirilmesi. Journal of Erzincan University Education Faculty, 18(2), 638-657.

Eshach, H. (2007). Bridging in-school and out-of-school learning: Formal, non-formal, and informal education. Journal of Science Education and Technology, 16(2), 171-190.

Güler, T. (2009). Ekoloji temelli bir çevre eğitiminin öğretmenlerin çevre eğitimine karşı görüşlerine etkileri. Eğitim ve Bilim, 34, 146-151.

Kırıkkaya-Buluş, E. (2008). Illköğretim 4. ve 5. sını öğrencilerinin fene karşı tutumları. VII. Ulusal Sınıf Öğretmenliği Eğitimi Sempozyumu'nda sunulan sözlü bildiri, Çanakkale.

Laçin-Şimşek, C. (2011). Okul dışı öğrenme ortamları ve fen eğitimi. C. Laçin-Şimşek (Editör), Fen öğretiminde okul dışı öğrenme ortamları içinde (s. 1-23). Ankara: Pegem A Yayıncilik.

Milli Eğitim Bakanlığı [MEB]. (2018). Milli eğitim bakanlı̆̆g fen bilimleri dersi (3-8. Sınıflar) ögretim programı. MEB Ankara.

Saraç, H. (2017). Türkiye'de okul dışı öğrenme ortamlarına ilişkin yapılan araştırmalar: içerik analizi çalışması. Eğitim Kuram ve Uygulama Araştırmaları Dergisi, 3(2), 60-81.

Sontay, G., Tutar, M. \& Karamustafaoğlu, O. (2016). Okul dışı öğrenme ortamları ile fen öğretimi" hakkında öğrenci görüşleri: planetaryum gezisi. Informal Ortamlarda Araştırmalar Dergisi 1(1),1-24.

Tatar, N. \& Bağrıyanık, K.E. (2012). Fen ve teknoloji dersi öğretmenlerinin okul dışı eğitime yönelik görüşleri. İlköğretim Online, 11(4), 883-896. 
Türkmen, H. (2010). İnformal (sınıf-dışı) fen bilgisi eğitimine tarihsel bakış ve eğitimimize entegrasyonu. Çukurova Üniversitesi Eğitim Fakültesi Dergisi, 3(39), 46-59.

Türkmen, H., Topkaç, D. D., \& Atasay Yamık, G. (2016). İnformal öğrenme ortamlarına yapılan gezilerin canlıların sınıflandırılması ve yaşadığımız çevre konusunun öğrenilmesine etkisi: tabiat tarihi müzesi ve botanik bahçesi örneği. Ege Eğitim Dergisi, 17(1), 174-197.

Uitto, A., Juuti, K., Lavonen, J. \& Meisalo, V. (2006). Students' interest in biology and their out-ofschool experiences. Journal of Biological Education, 40(3),124-129.

URL-1. Sürdürülebilir Kalkınma. Erişim adresi: http://www.surdurulebilirkalkinma.gov.tr/temel-tanimlar/ 19.05.2019 tarihinde erişilmiştir.

Var, M. \& Karaşah, B. (2010). Botanik bahçelerinin kullanıcılara sağladı̆̆ı eğitsel ve rekreatif imkânlar: Türkiye ve Dünya'dan örnekler. III. Ulusal Karadeniz Ormancılık Kongresi'nde sunulan sözlü bildiri, Artvin.

Yavuz-Topaloğlu, M. \&. Balkan-Kıyıcı, F. (2018). Okul dışı öğrenme ortamlarında yürütülen etkinliklerin öğrencilerin sosyobilimsel konulara ilişkin görüşlerine etkisi: Organ bağışı ve GDO. E-Uluslararası Ĕ̆itim Araştırmaları Dergisi, 9(1), 36-50. 
EK 1. Botanik bahçesi nedir? Broşürü
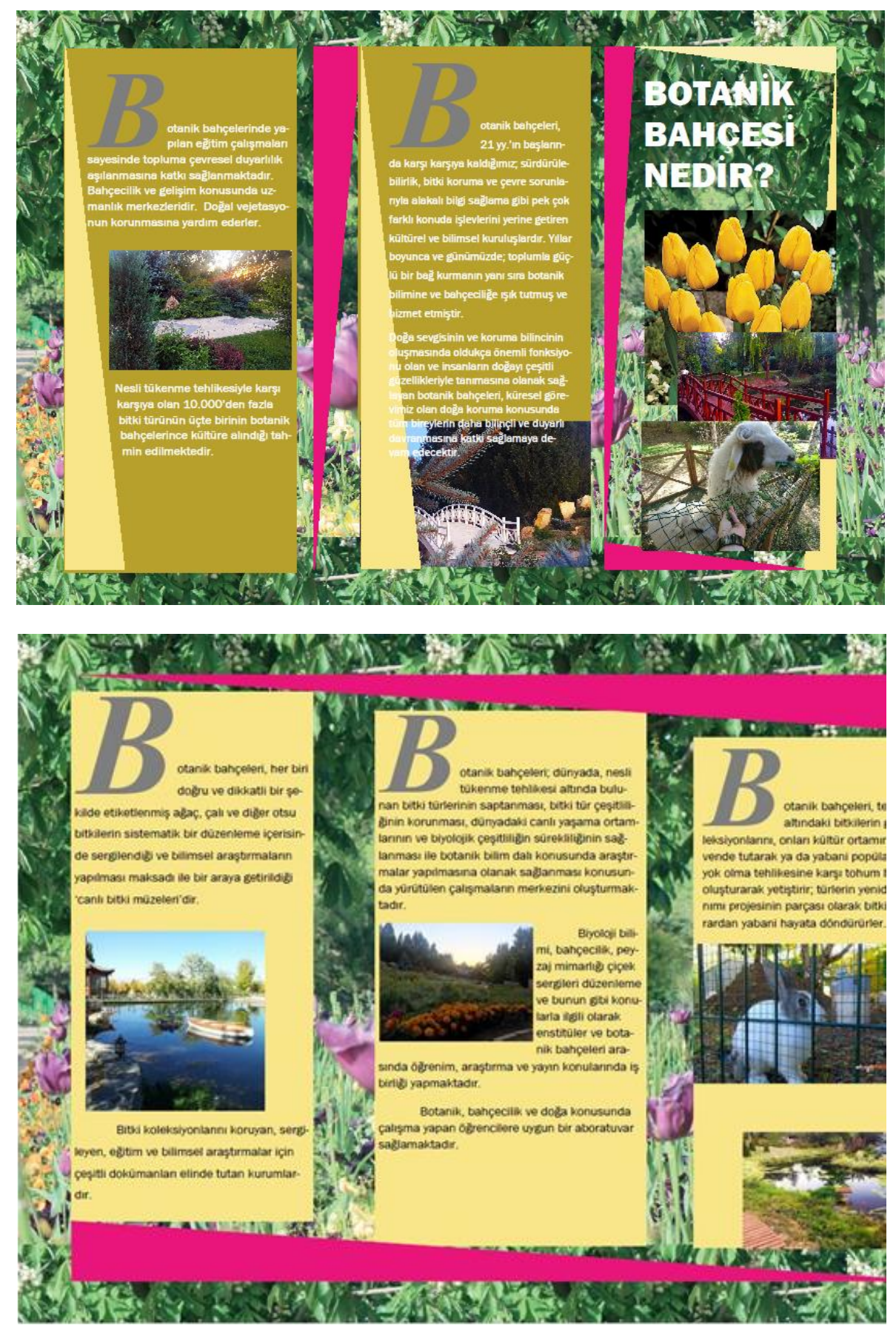
EK 2: Ata Botanik Bahçesi Tanıtım Broşürü

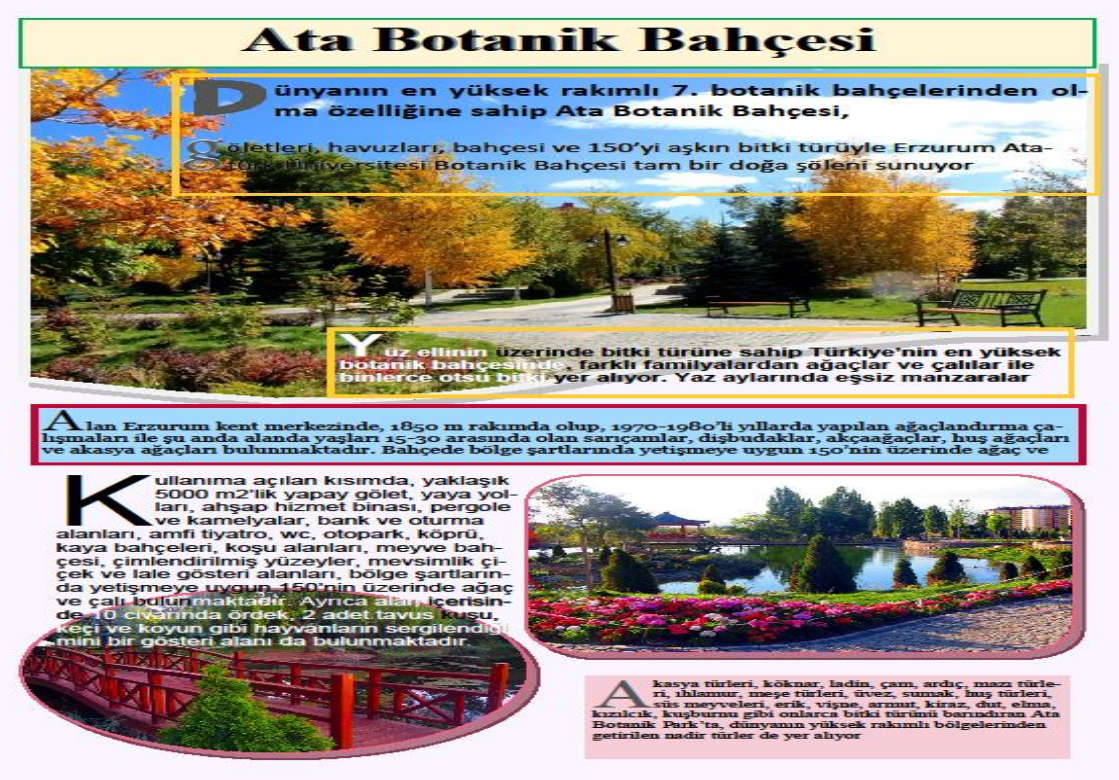

EK 3. Canlı Tanıma Formu

\section{CANLI TANIMA FORMU}

Canlının Adı:

Dâhil olduğu canlı

grubu

Ekosistemi

Canlının genel

görünümü

Bu canlı türü ile

çevrende karşılaşıyor

musun? Hangi sıklıkla? 
EK 4. Ekosistem Etkinliği

\section{EKOSISTEM ETKINLíĞi}

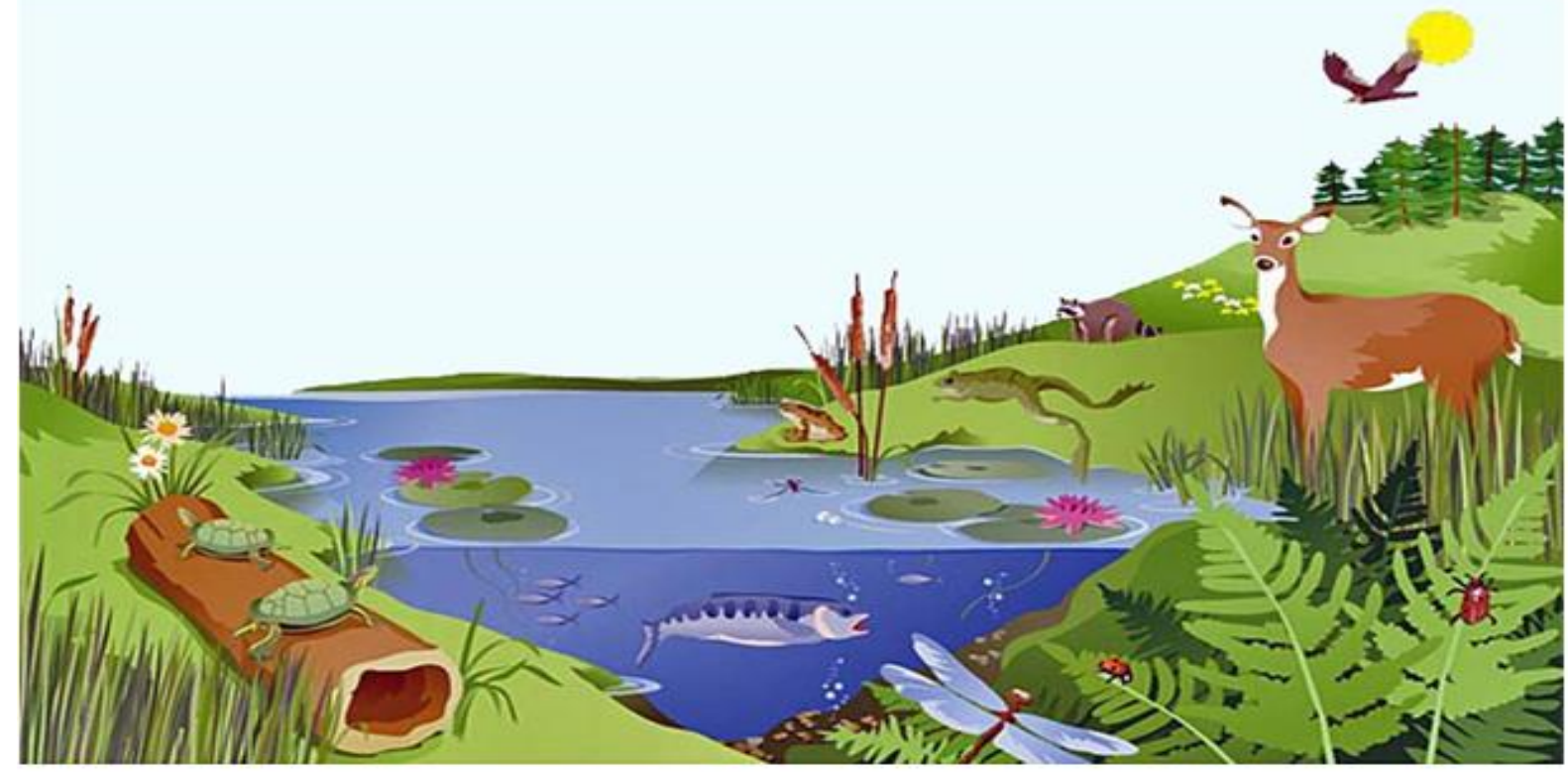

Yukarıda bir ekosistem örneği görüyorsunuz. Çevrenizde gördüğünüz ekosistemdeki biyoçeşitliliğe etki eden faktörleri işaretleyiniz.
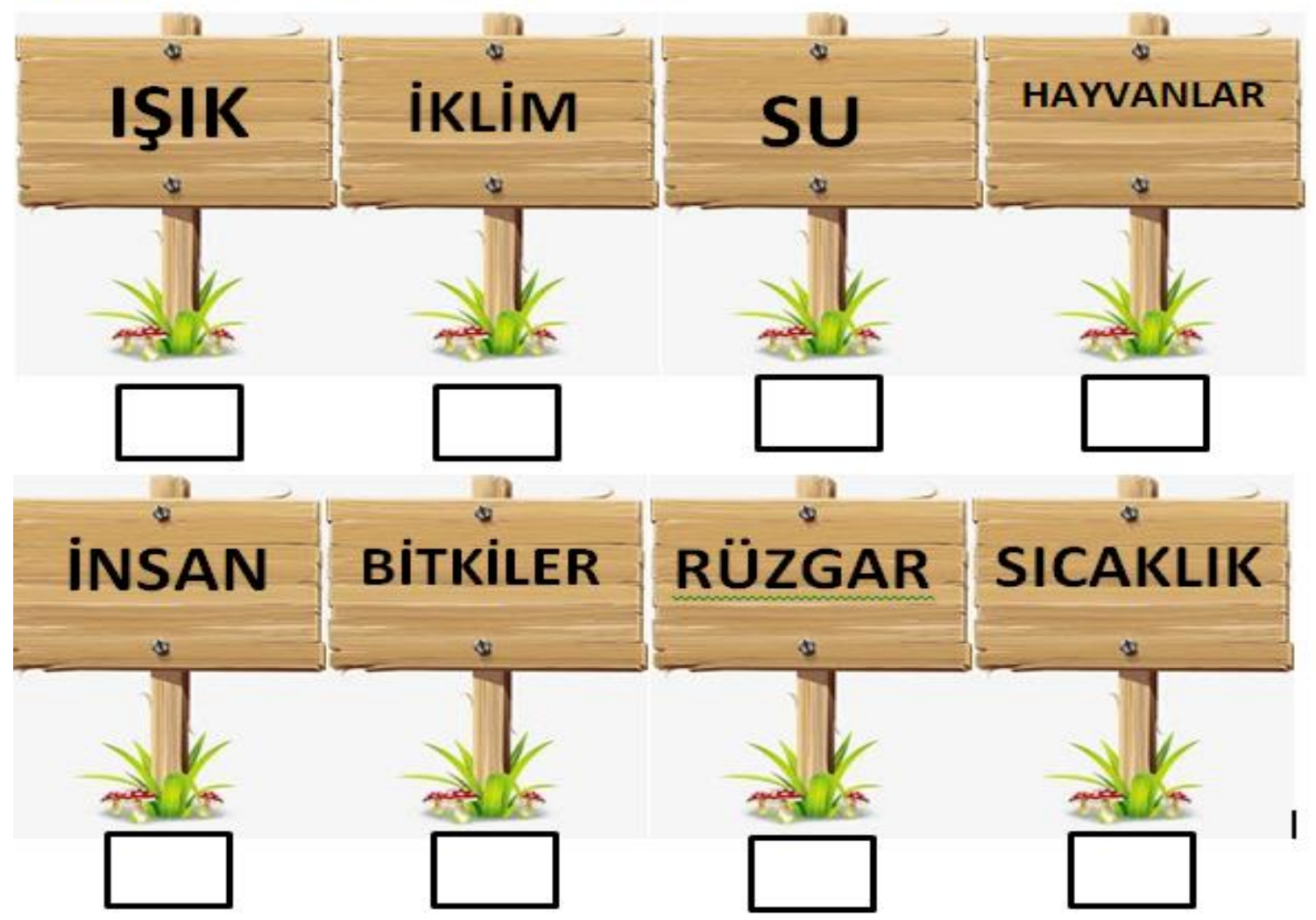
EK 5. Bak- Bul Eşleștir Etkinliği

\section{BAK-BUL- EŞLEŞTIR ETKINLIK KÂĞIDI}

Çevrenizde gördüğünüz canlı resimlerini aşağıdaki isimleri ile eşleştiriniz.

\begin{tabular}{|c|c|c|c|c|c|}
\hline Huş Ağa cı & Dişbudak Ağa cı & Aksa ağaç & Akasya ağacı & Sarıçam & Ladin \\
\hline$\ldots .$. & $\ldots .$. & $\ldots .$. & $\ldots$ & $\ldots .$. & $\ldots$ \\
\hline Şakayık bitkisi & Çalı & Otsu bitkiler & Ihla mur Ağacı & Lale & \\
\hline$\ldots .$. & $\ldots .$. & $\ldots . .$. & $\ldots$ & $\ldots .$. & $\ldots$ \\
\hline
\end{tabular}

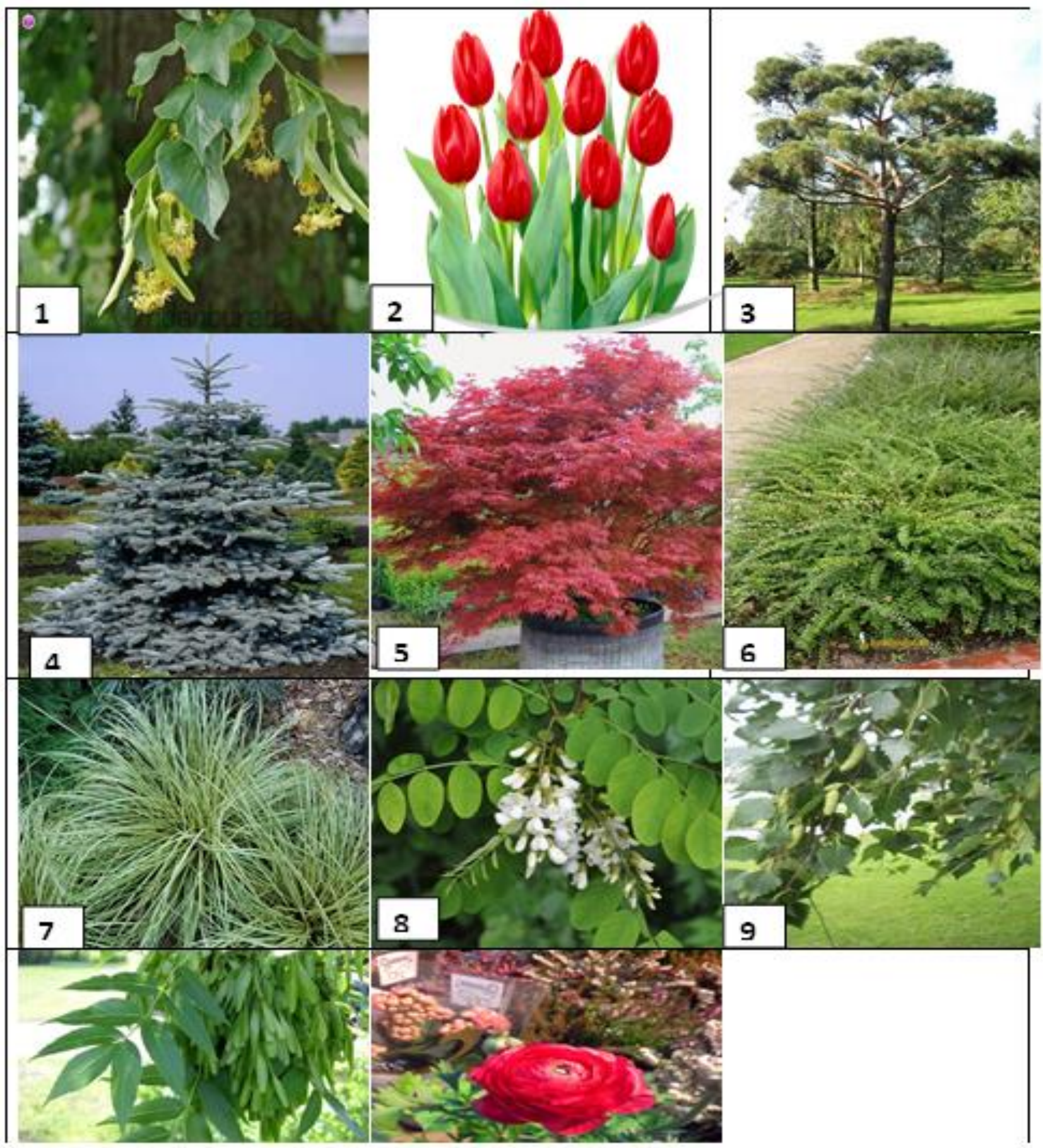


EK 6. Evvel Zaman İçinde Etkinliği

\section{EVVEL ZAMAN IÇINNE ETKINLIKK KÂGIDI}

Bir bölge de yaşayan can lıların sayı ve çeşitçe zeng inliğine biyoçeşittilik (canlı çeşitliliği) adı verilir.

Ülkemizin ūç tarafinın denizlerle çevrili olması, farklı yükseltilere sahip olması, farkıı mevsimlerin yaşanması, farklı iklim koşullanna sahip olmasından dolayı ūlkemizde çok sayda farklı tür canlt bulunmaktadır. Bu etkenler sebebiyle ülkemiz biyoçeșitlilik açsından zengin bir ülkedir. Ne var ki çeșitl etkenler sebebi ile bazı canlı türlerin in nesli tükenmiştir.

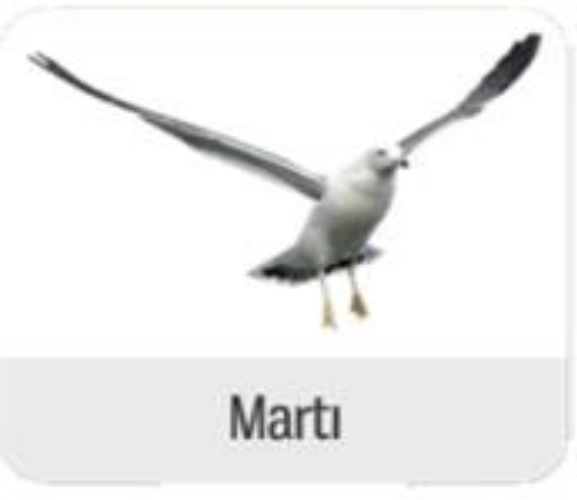

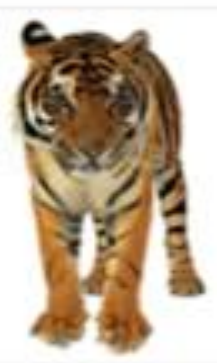

Leopar

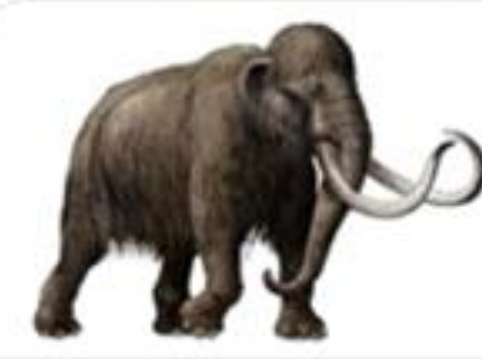

Mamut

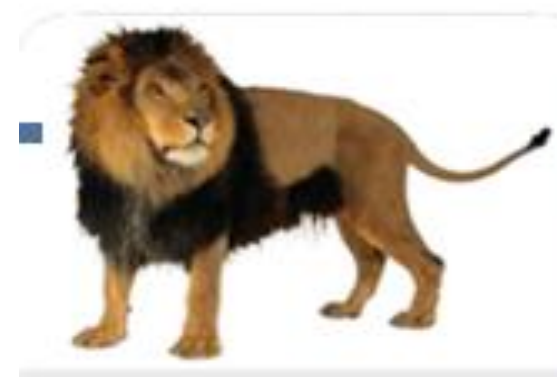

Aslan

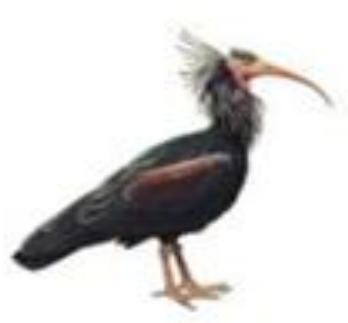

Kelaynak

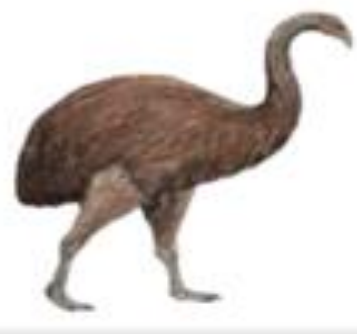

Moa

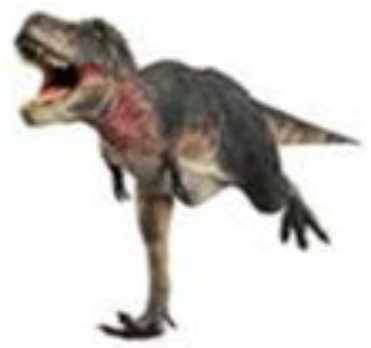

Dinozor

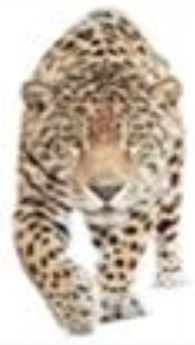

Anadolu leoparı

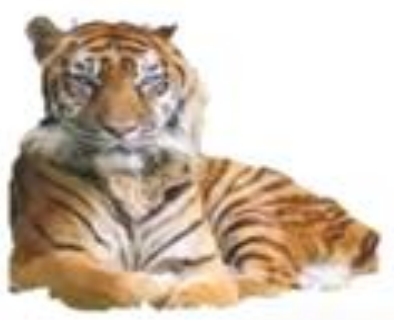

Hazar Kaplanı 